\title{
INTEGRATING COGNITIVE-BEHAVIORAL THERAPY AND GRATITUDE THERAPY FOR TREATING SOMATIC SYMPTOM DISORDER WITH SCHIZOID-AVOIDANT PERSONALITY FEATURES: A CASE REPORT
}

\author{
Karina Devany \& Elizabeth Kristi Poerwandari \\ Departemen Psikologi Klinis Dewasa, Fakultas Psikologi, Universitas Indonesia, Jl. Lkr. Kampus Raya, Depok 16424, Indonesia
}

Korespondensi: karina.devany@gmail.com

\section{INTEGRASI TERAPI KOGNITIF PERILAKU DENGAN TERAPI SYUKUR \\ UNTUK MENANGANI INDIVIDU DENGAN GANGGUAN SIMTOM SOMATIK DENGAN FITUR KEPRIBADIAN SCHIZOID-AVOIDANT: STUDI KASUS}

\section{Abstrak}

Artikel ini menjabarkan ulasan singkat mengenai penanganan pada kasus seorang perempuan berusia 22 tahun yang mengalami gangguan simtom somatik dengan fitur kepribadian schizoid-avoidant. Kondisi ini menyebabkan kecemasan dan hambatan dalam keberfungsiannya sehari-hari. Penghayatan diri negatif merupakan masalah utama yang memengaruhi emosi negatif, baik secara internal (somatisasi) maupun eksternal (hambatan relasi interpersonal). Ulasan ini bertujuan untuk memberikan gambaran integrasi pendekatan terapi kognitif perilaku dan terapi syukur (gratitude therapy) yang dapat menonjolkan perubahan pada penghayatan diri partisipan. Terapi syukur membantu dalam mengubah preokupasi klien terhadap sudut pandang negatif. Hasil dari efektivitas integrasi terapi kognitif perilaku dan terapi syukur pada kasus ini dijelaskan dalam diskusi dan limitasi penelitian.

\author{
Manuscript type: Case Report
}

Article history:

Received 17 April 2020

Received in revised form 23 June 2020

Accepted 6 August 2020

Available online 8 September 2020

\section{Kata Kunci:}

gangguan simtom somatik

kepribadian schizoid

terapi kognitif perilaku

terapi syukur

\begin{abstract}
This study presents a brief treatment report of a 22 -year-old-female, with a diagnosis of somatic symptom disorder and exacerbated by schizoid-avoidant personality features. Both conditions induced anxiety and many other difficulties in her functioning. Her negative self-views were the main issues that led to excessive negative emotionality, both internally (somatization) and externally (interpersonal relationship difficulties). The purpose of this case report is to illustrate an integrated treatment process consisting of cognitivebehavioral therapy and gratitude therapy. Gratitude therapy helps to alter the preoccupation of negative perspectives. Conclusions on the effectiveness of treatment were interpreted with an eye on the study's methodological limitations.
\end{abstract}

Keywords: cognitive-behavioral therapy, gratitude therapy, schizoid personality, somatic symptom disorder

\section{Impact and Implication in the Indigenous Context}

Somatic symptom disorder (SSD) is a condition characterized by distress due to persistent beliefs that one is suffering a serious medical condition. In the Indonesian culture, expressing discomfort in somatization is more socially acceptable than describing psychological distress. Cognitive-Behavioral Therapy (CBT) has vast empirical evidence in the Western practice for treating SSD. However, there is still a lack of Indonesian literature regarding the effectiveness of CBT for treating SSD. This study serves to provide an initial evidence on the topic from Indonesia perspective. Gratitude therapy is added as an adjunct intervention that focuses on enhancing thinking flexibility for individuals with rigid thought processes that consequently result in psychological and somatic complaints. 


\section{INTRODUCTION}

Somatic Symptom Disorder (SSD) in the Diagnostic and Statistical Manual of Mental Disorders (DSM) V (American Psychiatric Association [APA], 2013) is a condition of marked distress caused by persistent beliefs that one is suffering from serious medical conditions. SSD focuses on the extent to which a somatic symptom affects well-being in terms of thoughts, emotions, and behavior. Individuals with SSD usually have an unjustified medical explanation towards their somatic symptoms; therefore a psychological approach may help alleviate symptoms. In a collectivist culture, this kind of somatic complaint seems more pronounced as addressing psychological burden might indicate an interpersonal issue and disclosing such issues tend to be avoided (Susana, 2006). As a collectivist society, most Indonesian people believe that displacing psychological issues with somatic complaints are more tolerable than disclosing one's psychological problems.

Personality traits also contribute to the manifestation of SSD. People with high neuroticism and low extraversion (as in having interpersonal difficulties) tend to easily be aroused by their bodily sensations and are more likely to be dubious of medical results (Kirmayer, Robbins \& Paris, 1994). Schizoid personality profiles, as presented by this case, are marked by withdrawal from social relations and a limited range of emotional expressions (APA, 2013). Individuals with this personality features appear to have a lack interest in establishing relations and prefer solitary lifestyle. Millon, Millon, Meagher, Grossman, and Ramnath (2004) classified one of the schizoid features as the combination of schizoid and avoidant features (further termed schizoid-avoidant). Individuals with this characteristic essentially need to interact with others but are reluctant in establishing warm interpersonal relationship. This pattern may be formed by past experience that represses the individual's need of warm interpersonal relationship to avoid rejection (Millon et al., 2004). On the other hand, when relating to others, individuals with this characteristic lack adequate social abilities, which therefore causes anxiety in social interactions. Considering the possible complications that may occur due to the co-occurrence of SSD and schizoid-avoidant in an individual, such complications may warrant personalized treatment approaches or tailor-made forms of psychotherapy.

CBT is considered as an effective treatment modality for treating SSD through relaxation training, increasing positive behavior, increasing understanding of the association between thoughts and emotions, challenging invalid thoughts, behavioral experiments, and reducing behavior that 
sustains thought patterns which work to reduce symptoms (Allen, Woolfolk, Escobar, Gara, \& Hamer, 2006). The salient negative affect and interpersonal difficulties from the personality characteristic underlying SSD might impede the therapeutic benefits for particular clients. The gratitude technique which targets both cognition and affect might help support the CBT intervention. The gratitude technique is a psychotherapeutic intervention based on the positive psychology approach. When applying the gratitude technique, individuals realize the positive things they have experienced and that there are still positive things that exist beyond themselves (Emmons \& Stern, 2013).

Even though there still needs a substantial consensus regarding the prevalence of SSD in Indonesia, our observation indicates that Indonesian people tend to express their psychological issues with somatic complaints. There is still limited information about evidence-supported therapies to treat SSD within the Indonesian population. An international study has indicated that CBT appears to be a promising treatment for treating SSD (Allen et al., 2006). Therefore, this study primarily aims at filling the gap in the growing body of knowledge surrounding this issue by using a case study who were not only manifesting SSD, but also demonstrating a schizoid-avoidant personality features. Gratitude therapy as an approach in promoting a flexible way of thinking aims to alter the negative perspectives caused by the participant's personality style. This study may also contribute to provide insights regarding understudied topic of schizoid-avoidant personality in the Indonesian context.

\section{CASE STUDY}

Elia (aliased), a 22-year-old female, is an undergraduate student in her senior year, who was brought by a friend to seek psychological assessment at a community health center in West Java. She initially experienced concerns over having a serious illness in October 2018, when she felt a bump behind her knee and immediately sought information on diseases with such symptoms on the internet. Her internet exploration concluded that it was a cyst and she underwent consultations with three different physicians to justify her assumption on the disease; two of them concluded that she was medically fine and recommended no further medical procedure. However, Elia was sceptical with the physicians' diagnosis and since then she has developed greater sensitivity toward news ranging from serious diseases to deaths. 
Elia's concern over the somatic symptoms and diseases that she believed she might be suffering from were also intensified. When she felt only a slight uncomfortable bodily sensation, Elia would immediately think that she had a life-threatening disease and experienced panic attacks. She had no history of familial psychiatric illness and no record of substance abuse or medical conditions that might contribute to the onset and severity of her presenting complaints. Her condition disrupted her daily activities such as working on her college assignments.

Three months before the first meeting (July 2019), Elia initiated to undergo a psychological assessment with another psychologist for similar complaints. However, she sensed the therapist's prejudice and blamed her over her condition so she discontinued the session. Additionally, Elia's anxiety also affected her relations with others. Elia admitted that she became irritable toward others when she was in an anxious state. Elia reported that the condition has made her "difficult to be happy" and lonely.

To assess Elia's current condition, data was collected through clinical interview based on the DSM-V and by utilising psychological instruments (Hopkins Symptoms Checklist-25 [HSCL25] and OMNI Personality Inventory). HSCL-25 was used to measure psychological distress symptoms and as a baseline to assess alteration after treatment completion. OMNI was used to screen Elia's personality pattern that might particularly contribute to the subject's distress.

Elia's belief of helplessness that made her vulnerable to experience psychological distress in uncontrollable situations. The belief of helplessness manifested as somatic symptoms and a sense of helplessness in her interpersonal relationship. When experiencing minor bodily discomfort, Elia immediately associated the symptom as a serious ailment that further increased her anxiety. Elia also felt anxious about other people's acceptance and expressed it through anger toward the environment. The sense of helplessness hindered her from managing her anxiety in various situations. She showed a tendency to focus on her anxiety and to ruminate on negative thoughts, which triggered heightened depressive and anxiety symptoms that limited her daily performance.

Elia had difficulty managing her anxiety because she did not have the appropriate coping skills. When faced with a problem, Elia withdrew and behaved in a way that reinforced her negative emotions. When her withdrawal was ineffective she started to react by expressing her negative emotions excessively and inappropriately. Elia admitted that she needed other people but lacked adequate social skills to satisfy her need. She also believed that others would blame and reject her. She then assumed that by acting out, she would gain people's attention and help. She blamed her surroundings when facing problems as she felt that other people were responsible for her condition. 
The assessment and treatment were conducted by the the first author, as an intern clinical psychologist. Sessions were delivered under the supervision of a licensed clinical psychologist (the second author). The assessment was administered in three sessions. Based on the assessment, Elia had somatic symptom disorder indicated by the somatic symptoms that caused psychological distress and disrupted her functioning - she was fixated on the symptoms and experienced excessive anxiety over them. Elia also showed schizoid-avoidant personality features. Such personality features were manifested in anhedonia, persistent negative affect, low self-esteem, and inadequacy. She also believed that she did not have warm social relationship, preferred solitary activities, worried over judgment from others, and avoided of social activities in fear of receiving poor treatment.

To address Elia's chronic presentation of symptoms, two interventions were integrated; CBT and gratitude therapy tailor-made for her treatment plan. The therapy was delivered in seven sessions that lasted 2-3 hours each session. The treatment objective was to modify Elia's belief over her helplessness so that she could have a more positive view of herself and her surroundings, as well as have more flexible thought patterns. The result of belief modification may help Elia to deal with unpleasant situations and manage her irrational concerns, with secondary outcomes in improved mood and anxiety.

Given the presence of anxiety over somatic symptoms, Elia's experience can be explained through the cognitive-behavioral theoretical model (Westbrook, Kennerley, \& Kirk, 2011). CBT was given to address Elia's catastrophic thinking on somatic symptoms, as beliefs of helplessness caused her to immediately worry about different bodily sensations. In the administration of CBT, there are several aspects suggested by Allen et al. (2006), which include relaxation to manage tension, discussing the association between cognition and emotions and its effects toward experienced symptoms, and cognitive restructuring on core beliefs. The relaxation technique administered was diaphragmatic breathing. The therapist explained the concept of CBT so that Elia could identify the thoughts, emotions, and behavior she produced when experiencing somatic symptoms. The therapist also informed her about the interconnection between these three aspects. Homework on thought records was also given for Elia to practice identifying thought patterns related to somatic symptoms. Elia was able to see that her negative automatic thoughts caused anxiety and resulted in unproductive behavior. Disease-seeking behavior only reinforced her beliefs about having a serious illness and heightened her anxiety. The therapist conducted counter change talks to Elia's catastrophic thoughts and she was assigned to practice applying it to herself. 


\section{Vulnerability Factor}

Elia's belief of self-helplessness, which made her prone to be preoccupied with negative thoughts.

\section{Catastrophic Prediction}

She had catastrophic thoughts about having serious illness, needing surgical treatment, and dying.

\section{Catastrophic Belief Unchallenged}

1. Elia only experienced short-term relief from the physicians' examination.

2. Her anxiety increased.

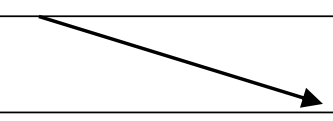

\section{Maintaining Behavior}

1. Elia sought reassurance from physicians.

2. Elia did more research to support her assumption about the illness.

Figure 1. Elia's CBT Model of Health Anxiety (adapted from Westbrook et al. (2011))

Gratitude therapy, which is based on the positive psychology approach, was provided as the technique that focused on an individual's ability to realize the positive things in their lives and realize their external resources to manage psychological challenges (Emmons \& Stern, 2013). This technique was aimed at Elia's core belief, to enhance her perception of self-control. There were two techniques used in this modality, which were identifying three good things and Naikan. In identifying three good things, Elia was asked to write down three good things she was thankful for each day. Naikan was a technique directed to how Elia gave meaning to interpersonal relation. There were three reflective questions in this technique: what have I received from others?, what have I given to others?, and what have I done that caused trouble and difficulties to others? (Krech, 2001).

In the beginning of treatment phase, Elia frequently resisted and defended herself for her current condition. However, although being resistant, she still attended all sessions and arrived punctually. As the therapy sessions progressed, Elia demonstrated constant improvement, reflected through the HSCL-25 scored, which indicated reduction of psychological distress symptoms - from 2.3 in pre-treatment to 1.8 at post-treatment (scale ranges: $1-4)$. The intervention also demonstrated how Elia became aware of her helplessness belief that caused dissatisfaction with her condition and vulnerability to negative emotions such as anxiety and anger. It appeared that the CBT intervention in combination with gratitude therapy generated a new belief in Elia and enabled her to reflect, 
"Rather than thinking about my anxiety, I would rather think about good things that happened." Elia was able to see her thought patterns and generated new and flexible thinking patterns. In her social relationship, Elia also demonstrated a willingness to understand other people's points of view. It was concluded that gratitude therapy augmented the CBT that targeted her core beliefs. Elia started to replace her old belief ("I am helpless") with the new one ("I can make myself happier"). After 2 months of weekly therapeutic sessions, Elia admitted that she had lowered frequency and intensity of somatic complaints. Table 1 summarises the Elia's attitude alteration during intervention.

Table 1.

Elia's Attitude Alteration During Intervention

\begin{tabular}{|c|c|c|c|c|}
\hline Time & Event & Beliefs & Emotion & Behavior \\
\hline Pre-Intervention & & $\begin{array}{l}\text { She thought she had } \\
\text { a serious medical } \\
\text { condition. } \\
\text { She thought no one } \\
\text { could understand } \\
\text { her. }\end{array}$ & $\begin{array}{l}\text { She felt extremely } \\
\text { anxious, helpless } \\
\text { and irritable. }\end{array}$ & $\begin{array}{l}\text { She sought } \\
\text { justification for her } \\
\text { thoughts toward } \\
\text { illness. } \\
\text { She blamed her } \\
\text { surroundings. }\end{array}$ \\
\hline Post Intervention & $\begin{array}{l}\text { Elia felt bodily } \\
\text { sensation. }\end{array}$ & $\begin{array}{l}\text { She thought that she } \\
\text { had control to } \\
\text { manage her } \\
\text { condition. } \\
\text { She acknowledged } \\
\text { that she was the one } \\
\text { who put others in } \\
\text { trouble more often. }\end{array}$ & $\begin{array}{l}\text { She felt reduced } \\
\text { negative affect and } \\
\text { increased } \\
\text { happiness. }\end{array}$ & $\begin{array}{l}\text { She was able to } \\
\text { generate new thoughts } \\
\text { on her condition. } \\
\text { She took a healthier } \\
\text { lifestyle. } \\
\text { She was able to } \\
\text { understand other } \\
\text { people's perspectives. }\end{array}$ \\
\hline
\end{tabular}

\section{DISCUSSION}

This report provides a preliminary insight that CBT integrated with gratitude therapy could be effective in reducing somatic symptoms and accompanying psychological distress. In this case, if CBT was administered alone to address the somatic symptoms disorder, it would have been more difficult for her because she was preoccupied with negative thoughts. Therefore gratitude therapy was administered to habituate the subject into practicing flexibility in observing things, which could further help her to view events more positively or, at least in the less negative way. The subject was then able to cooperate more within the therapy session. This case study specifically presented a 
brief application of CBT integrated with gratitude therapy for a case of SSD with schizoid-avoidant personality features. The characteristic of SSD was recommended to be treated with the CBT approach, but with the co-occurrence of personality feature, the gratitude therapy was utilized to generate a more flexible and neutral standpoint from negative views towards her condition and toward others.

The interpretation of this study should be within the precaution of notable methodological limitations. First, as a single case study, the study has a limited representative power to justify the findings. Second, the HSCL-25 utilized in this study only measured anxiety and depression symptoms and did not specifically measure somatic symptoms, hence it might not be the best indicator to quantitatively demonstrate client's improvement. Future studies could utilize specific psychological instruments that also includes somatic symptoms evaluation. We also recommend more studies focusing on the effectiveness of integrating both approaches given the promising outcome based on this case study.

In conclusion, this study contributes to the literature by providing preliminary evidence in supporting the integration of CBT and gratitude therapy in Indonesia, based on the outcome of a client's negative self-beliefs. This case study demonstrated that CBT enhanced with gratitude therapy could be effective in treating the subject with SSD. The gratitude approach is particularly effective as an adjunct to support the treatment given by improving flexible thinking patterns, especially since the subject's condition was comorbid with schizoid-avoidant personality features.

\section{REFERENCES}

Allen, L. A., Woolfolk, R. L., Escobar, J. I., Gara, M. A., \& Hamer, R. M. (2006). Cognitivebehavioral therapy for somatization disorder: A randomized controlled trial. Archives of Internal Medicine, 166(14), 1512-1518. doi: 10.1001/archinte.166.14.1512

American Psychiatric Association. (2013). Diagnostic and statistical manual of mental disorders (DSM-5®). American Psychiatric Pub.

Emmons, R. A., \& Stern, R. (2013). Gratitude as a psychotherapeutic intervention. Journal of Clinical Psychology, 69(8), 846-855. doi: 10.1002/jclp.22020

Kirmayer, L. J., Robbins, J. M., \& Paris, J. (1994). Somatoform disorders: Personality and the social matrix of somatic distress. Journal of Abnormal Psychology, 103(1), 125-136. 
Krech, G. (2001). Naikan: Gratitude, grace, and the Japanese art of self-reflection. Stone Bridge Press.

Millon, T., Millon, C. M., Meagher, S. E., Grossman, S. D., \& Ramnath, R. (2004). Personality disorders in modern life. John Wiley \& Sons.

Susana, T. (2006). Somatisasi dalam budaya kolektivis ditinjau dari teori pemaknaan Nelson: Kritik terhadap psikoanalisa klasik. Buletin Psikologi, 14(2), 89-104.

Westbrook, D., Kennerley, H., \& Kirk, J. (2011). An introduction to cognitive behaviour therapy: Skills and applications. Sage Publications. 